\title{
BRITISH PROTECTIONISM AND OIL INDUSTRY PRIOR TO THE ESTABLISHMENT OF PETRONAS
}

\author{
SAIFUL KHAIRI KAMARUDIN*
}

\begin{abstract}
The existence of protectionism policy in Malaya and Borneo had been practised by the British specifically in the oil industry during colonialism. This policy was to prevent the largest American oil corporation, from dominating the oil market in Southeast Asia. The two British oil companies, the Anglo-Saxon Company and Shell Company in the early 20th century completed their business relationship with the Dutch oil company to control the oil industry in Southeast Asia. Oil producer colonies in Southeast Asia was solely granted oil supply through British oil company to prepare the outbreak of the First World War. This marked the height of British protectionism by providing continuous oil supply to the British Navy and expanding oil exports during the First World War. Later, PETRONAS adopted protectionism and monopoly strategies to increase equity ownership of Malays in the oil and mining industry.
\end{abstract}

Keywords: Petroleum industry; Protectionism; Foreign oil company; World war 1; National oil company.

\section{INTRODUCTION}

This paper examines the existence of the policy of protectionism in Malaya and Borneo practised by the British specifically in the oil industry during the era of colonisation in the $19^{\text {th }}$ and $20^{\text {th }}$ centuries. The British strongly practised a free trade policy after the Industrial Revolution in the 19th century. ${ }^{1}$ However, the practice was not carried out in its colonies when it came to the oil industry. In this industry, the British strongly propagated mercantilis ${ }^{2}$ or monopoly practice through protectionism. ${ }^{3}$ The reason behind the British policy of protectionism was to prevent the Standard Oil Company, the largest American oil corporation, from dominating the oil market in Southeast Asia.

To stem the expansion of Standard Oil business operations in Southeast Asia, two British oil companies, the Anglo-Saxon Company and Shell Company in the early $20^{\text {th }}$ century, completed their business relationship with the Dutch oil company, the Royal Dutch Company by forming a partnership in Southeast Asia, known as the Royal Dutch Shell Petroleum Company. This oil partnership was promoted to directly control the oil-related economic activities of colonies under British and Dutch administration in Southeast Asia.

Prior to the First World War, the British protectionism policy in the oil industry reached its height when the British government granted security of oil supply to its oil producer colonies through their oil company. The Royal Dutch Shell Petroleum Company was responsible for 
providing continuous oil supply to the British Navy and expanding oil exports during the First World War.

Scope of the study begins with an account of operating oil companies in Malaya by Foreign Oil Company (FOC) in 1870s until the new government of Malaya (Malaysia) produced more concession agreements for the FOCs to explore more offshore oil deposits in Borneo as well as in Malay Peninsula in1960s.

\section{BRITISH PROTECTION FOR OIL DOMINATION}

The United States dominated the international petroleum industry in the $19^{\text {th }}$ century, since they were the first to produce oil in large quantities, and it justified their commercial exploitation in several continents. Five of seven major international oil companies in the early 1900s were American - Standard Oil (New Jersey), Texaco, Gulf, Mobil, and Standard Oil of California; then there was British Petroleum, which is almost half owned by the British government, and Shell, which is Anglo-Dutch with twin headquarters in London and the Hague. ${ }^{4}$ However, Britain in the later decades of the $19^{\text {th }}$ century did not see the oil industry as particularly to their interests ${ }^{5}$. This provided the opportunity for the American Standard Oil Company ${ }^{6}$ expand its commercial oil interests abroad by marketing in Southeast Asia. Before World War I, it was already commercialising oil in Singapore.

In the early twentieth century, oil became Britain's principal energy source. The need for great oil consumption by the British created great competition of oil business between the British and American capitalists. For them, cheaper oil should be produced at lowest operation cost. The cheapest oil production could be generated in the Far East and Southeast Asia through strategic partnership with the local people and other FOC.

The competition of producing cheaper oil supply was an issue for the British when the American oil corporation, Standard Oil, was dominating the oil distribution industry in Southeast Asia. As a result, Standard Oil's presence drove the British capitalists into a partnership alliance with the Dutch oil company as a business strategy to dominate the oil market share in the Far East and Southeast Asia.

\section{Standard Oil in Malaya and Singapore}

Oil exploration and production activities were yet to be established in Malaya during early British colonialism. However, at that time American Standard Oil used Singapore as a centre of oil distribution in Southeast Asia. Oil was mainly imported from the United States, Russia, Burma, and Sumatera, whose oil producers were American merchants who had business relationships with Standard Oil. ${ }^{7}$

Cased oil from the United States was kept in warehouses near the harbour, for distribution around the Peninsula. ${ }^{8}$ Standard Oil introduced trade using cased oil after realising that carriage in barrels proved difficult and expensive. Standard Oil kerosene in its distinctive blue tins soon spread throughout the world. Cases of American oil reached Singapore in small quantities in the $1860 \mathrm{~s}^{9}$ 
Even until the early of $20^{\text {th }}$ century, Standard Oil of New Jersey had a significant impact on oil trading in Singapore with Tanjong Pagar as storage for fuel oil distribution. Jersey Standard's principal product in the 1920s was gasoline after kerosene, which used to be their principal product in the early 1910s. ${ }^{10}$ In 1922, they began to retail gasoline in Singapore. The demand for gasoline in 1930 grew with the start of commercial air traffic and the aviation fuel market. Subsequently, the automotive industry expanded, and the need for gasoline to replace kerosene contributed to the increase of oil distribution in Southeast Asia. In 1921, Jersey Standard Oil established its first service station in Kuala Lumpur. The single hand-operated pump would serve nearly 2,000 vehicles in the Klang Valley. ${ }^{11}$

The presence of Standard Oil in Malaya and Singapore since the mid- $19^{\text {th }}$ and early $20^{\text {th }}$ centuries had demonstrated that oil marketing strength went to American oil capitalists and enriched oil traders and retailers who had business relationships with Standard Oil in the region. This indirectly undermined oil producers who had direct contact with the British colonial government in Southeast Asia. Rather than American owners, the Anglo-Saxon and Shell Company - owned by the British - was supposed to get distribution privileges.

\section{Shell and Standard Oil Rivalry}

Shell and Standard Oil rivalry in Southeast Asia started when the domination of oil supply in the region was controlled by Standard Oil in the 1870s, and they used Singapore as a centre of oil distribution in Southeast Asia. The oil distribution market for Standard Oil was not only significant in Singapore but also prospered in Penang. Twenty years later, the first Standard Oil products made their debut in 1893 in Malaya, with the arrival of the SS Calm in the Butterworth docks, Penang. ${ }^{12}$ Their primary products at the time consisted of oil as fuel for light, lubricants, paraffin, and solvents. ${ }^{13}$ Two years before 1893, the development of oil storage in Singapore was initiated under Shell's establishment of bulk storage. This marked the beginning of oil industry rivalry between Shell and Standard Oil in Southeast Asia.

The Shell Company also marked an oil distribution business in Malaya in 1891 when Marcus Abraham, a nephew of Marcus Samuel, arrived in Singapore to build storage facilities at Pulau Bukom to support Shell's oil distribution operations in Asia. This also supported Samuel's tanker which came from Russia to Singapore via the Suez Canal. Later in 1898, Standard Oil expanded its Singapore oil operation and added storage in Pulau Sebarok. ${ }^{14}$

Nevertheless, Samuel still could not compete with Standard Oil in the Asian market because their Asian customers preferred Standard Oil's kerosene cans and products. ${ }^{15}$ The Shell Transport and Trading Company under Marcus Samuel was registered in $1897 .{ }^{16}$ At the dawn of the new century, it was already a formidable rival to Standard Oil in the Asian region, owning 30 ships and a whole network of depots in the East. ${ }^{17}$

The competition of Asian oil trade began to grow because of the growing participation of major oil companies in the region. The impact was that oil export activities in Singapore significantly contributed to the domestic economy in the 1930s. In 1950 , about $20 \%$ of all vessels going through the port were involved in the oil trade. ${ }^{18}$

The oil distribution rivalry between Shell and Standard Oil was declared by Heinreich Riedeman, Standard Oil's chief executive in Europe, who had a lifelong desire to crush Shell, which he claimed was a principal rival to Standard Oil. ${ }^{19}$ From 1920 to 1930, Shell rapidly 
expanded under Henri Deterding, the Royal Dutch Shell Company's second Managing Director after August Kessler. During his time, Shell's exploration was the biggest in the world. ${ }^{20}$

Under Deterding's leadership, he introduced the Policy of Straight Line ${ }^{21}$ which consequently gave an edge to Shell to market oil cheaply. More than that, he introduced an autonomous policy for Shell's subsidiaries to act as an integral part of the country rather than just producing a profit. This generated openness to its shareholders and increased joint ventures with local governments. At the same time, the British colonial government paved the way for the Shell Company to establish business relationships with the Anglo-Saxon Petroleum Company due to many of its shareholders being local and British officials.

Royal Dutch and Shell in the Far East

One of the earliest British state oil corporations that penetrated the oil trading business in the Far East was the Anglo-Saxon Petroleum Company. ${ }^{22}$ Its head office was in London; it cooperated with the Royal Dutch Company, which was owned by the Dutch and whose head office was in The Hague. Both oil companies were responsible for operation activities. The Anglo-Saxon Petroleum Company managed transportation and storage activities, whereas the Royal Dutch Petroleum Company managed exploration and production activities.

In 1903, the Royal Dutch, Anglo-Saxon Petroleum Company, 'Shell' Transport and Trading Company and the French trading house of Rothschild combined their marketing interests in the Asian market and formed the Asiatic Petroleum Company. ${ }^{23}$ The marketing activities in Borneo remained in the hands of the Asiatic Petroleum Company. The Asiatic marked the beginning of oil commercialisation in the Far East and Southeast Asia. ${ }^{24}$

It was Marcus Samuel, the son of an East London Jewish merchant, who became the first European to trade oil in the Far East and Southeast Asia. He was the founder of the Shell Company. He became the first man to invest in the oil business in Sarawak in 1909when he reported that oil was found in Miri. ${ }^{25}$ In 1878, Samuel and his brother set up their trading commodities in the Orient, specialising in trade with Japan. One of the many commodities that they traded was Japanese coal through the Far East, and this, in turn, led them to think of oil. ${ }^{26}$ In 1898 he set up the Nederlandsch-IndischeIndustrie-en Handel Maatschappij, with its oil concession in Borneo. Subsequently, the famous oil complex of Balikpapan was to be created. ${ }^{27}$ During that time, Standard Oil of America dominated the oil distribution market in Asia.

Consequent on the formation of the Asiatic Petroleum Company through the British oil companies (Anglo-Saxon and Shell) and Royal Dutch Company, the market share of oil distribution for Shell in the Far East had improved more or less equal to Standard Oil. In 1902, Frederick Lane was responsible for the Royal Dutch and Shell together buying the interests of Shell and the Paris Rothschild's with Royal Dutch as a joint company with equal shares. ${ }^{28}$ As a result, the Asiatic Petroleum Company was formally incorporated in 1903 and facilitated Deterding's taking advantage of Asiatic to use Shell's facilities to increase the market for Royal Dutch Oil. ${ }^{29}$ 


\section{Anglo-Dutch Oil Partnership}

The competition of producing cheaper oil was an issue for the British when Standard Oil dominated the oil distribution industry in Southeast Asia. As a result, Standard Oil's presence drove the British capitalists into a partnership alliance with the Dutch oil company as a business strategy to dominate the oil market share in Southeast Asia as well as in the Far East.

In early $20^{\text {th }}$ century, British and Dutch oil companies came together to develop oil concession cooperation and agreements. As mentioned earlier on the formation of Asiatic Petroleum Company from the cooperation of the Royal Dutch Company, Anglo-Saxon Petroleum Company, 'Shell' Transport and Trading Company. They initiated an oil business strategy to combine their oil exploration interests, and thus formed Shell Petroleum Company through a regional cooperation in the Far East and Southeast Asia.

The cooperation was formed to maintain and dominate oil resources in the Far East and Southeast Asia. Other than that, the British tried to inspire the local people in its colonies to acknowledge British rule by giving industrial management shares, providing employment in the oil fields and leveraging oil concession agreements with important local leaders. ${ }^{30}$ This was to prevent the Standard Oil Company of America from penetrating the oil market in Southeast Asia as local leaders would be loyal to the British and the Dutch.

This strategy did not happen only in the Far East and Southeast Asia, but also in the Near East. At the beginning of the $20^{\text {th }}$ century, the British Anglo-Saxon Oil Company gained bigger oil concessions in the Near East. At that time, oil was struck in Iran by British explorers. The discovery immediately prompted Britain's more ardent interest in Iran's internal affairs. ${ }^{31}$ Just before the First World War, a joint British-Dutch oil company was set up to explore oil in the then-Turkish Iraq. British oil interests were decisive for the dismemberment of the Ottoman Empire and the ensuing political fragmentation of Arab lands. ${ }^{32}$ British oil interest in the Middle East was already predominant. ${ }^{33}$ Due to the discovery of oil at Abadan in Iran, a new concession company, the Anglo-Persian Oil Company, was formed in 1909.

With bigger oil concession gained in the Near East, the Anglo-Saxon Petroleum Company had indirectly made Britain shift the energy source from coal to oil. ${ }^{34}$ The urgent task for British oil companies was to supply cheaper oil to the country and its colonies in Asia. All British colonies had to play a significant role to establish an energy policy that gave preference to companies that offered cheaper oil distribution. As a result, the British colonial government made a direct intervention in the oil business that gave privilege to the British oil companies operating in the Near East and Southeast Asia.

\section{Cheaper Oil in Colonies}

In the early $20^{\text {th }}$ century, oil became Britain's principal source of energy. Oil consumption by the British created competition between the British and American capitalists. They needed cheaper oil to be produced at lower operation costs. The cheapest oil production could be generated in the Far East and Southeast Asia through a strategic partnership with the local people and other foreign oil companies (FOC). ${ }^{35}$

The consumption of oil in new mechanisms of machine invention and innovation in factories created substantial operating costs and decreased operating profits. Oil needs to be 
produced at low cost to boost factory operation performance, the efficiency of product delivery, and effectiveness of capital employed for business results.

To achieve this, cheaper oil needed to be found outside Europe. Fortunately for the British, they had colonies in the Near East and the Far East where oil could be produced easily through the political and economic intervention of supreme colonial power. As a result, the British capitalists and industrialists' oil hunger persuaded the government to add new colonies to acquire new revenue for their countries as well as avenues for creating cheaper oil production. ${ }^{36}$ Meanwhile, the British had to compete with other European countries that were also looking for oil in the East.

\section{BRITISH OIL INDUSTRY IN SARAWAK}

Sarawak was the principal state of oil exporters for the British colonial empire; it marked the beginning of Malaysian history in petroleum production. ${ }^{37}$ In the early 19th century, Sarawak was ruled by a middle-class English adventurer, James Brooke. The entire activity of oil production in Sarawak was actively managed by the British through the help of the Rajah Brooke family. It was known that oil businesses in Sarawak became prosperous under Rajah Brooke's rule.

Consequent upon Sarawak growing rich in oil, the British government saw the need for social change that followed the Malayan economic model in the mining industry, in which stratification of socio-economic classes through the division of race in different economic sectors. As a result, the Brooke government that ruled Sarawak introduced open labour policy to assist British oil investors and traders and enable them to produce cheaper oil.

In the late $19^{\text {th }}$ century, Brooke's free market policy changed to protectionism policy. British proxy oil companies such as Anglo-Saxon Petroleum Company and the Royal Dutch Petroleum Company held the dominant market share in oil activities in the Far East and Southeast Asia after facing aggressive oil distribution by Standard Oil, owned by the United States.

\section{Rajah Brooke's Social Economic Policy}

Rajah Brooke's role in Sarawak on behalf of Englishmen was to protect the trader while fostering native welfare which he was permeated with Raffles' vision of a benevolent English administration..$^{38}$ Brooke introduced major social change in Sarawak, which consequently changed a cultural identity for Sarawak. His free-market policy enabled exploitation of oil deposits by FOCs in Sarawak and caused him to decrease the indigenous people's role in the oil industry. ${ }^{39}$ Most significant was the tendency to view the population in terms of ethnic communities which shared some aspects with colonial administrations in the Peninsular Malay States. ${ }^{40}$

The Brookes had an interest in cultivating economic activity through the division of linguistic and cultural groups in Sarawak, with each group having distinct roles divided into three basic categories. Chinese migration was encouraged, and the Chinese would then trade, cultivate, or mine. Under James Brooke's son, Charles Brooke, the Chinese community grew 
considerably, and without any European competition, they were able to assume a dominant position in Sarawak's economy. ${ }^{41}$

The Brookes' socio-economic class was based on the free-market policy propagated by the British. When oil was discovered in Miri, it was the free-market policy that proved that the oil industry could not be run commercially by the local people because oil was expensive and only limited for local usage. By supporting the British, the Brookes managed to formulate an oil labour policy for the benefit of FOCs by pushing cheap Chinese and Javanese labour from the rubber industry to the petroleum industry. ${ }^{42}$ This was to ensure that FOCs reduced operating costs efficiently in the oil business.

Cheap labour from China could help reduce operating expenses in the oil business. However, this could be successfully done only with the strong intervention of Britain's economic policy to promote the extension of oil usage, not only for local usage but also for the international industry as well as British military growth. Therefore, cheaper labour supported British economic policy, and this was an issue for oil capitalists. In return, the British government opened access for cheaper Chinese immigrants to help them realise their oil business objectives.

\section{Oil Discovery in Sarawak}

Sarawak marked the beginning of oil production for Borneo's income on exports commodity. Production of oil in a large quantity began with extensive exploration for oil in northern Sarawak. The Anglo-Saxon Petroleum Company, through a partnership with Shell Company, took an advance step in Borneo to pre-empt American Standard Oil from dominating oil market exploration in Southeast Asia.

Initial crude exploration in Sarawak began in 1882 when petroleum was discovered in Miri by the British Resident of Baram District when he noticed that local Malays collected oil and used mainly for medicinal purposes, lighting lamps, and caulking boats. ${ }^{43} \mathrm{~A}$. H. Everett, a member of the North Borneo Chartered Company or British North Borneo Company, predicted that Miri was rich in oil. His observation in Miri during the 1870 s was that "a small native industry flourished in the area, oil being obtained for local use from shallow surface wells". ${ }^{4}$

Shell Company was responsible for the rapid growth of oil production in Sarawak. Shell began oil exploration in Sarawak together with the coming of the Anglo-Saxon Petroleum Company after the Royal Dutch Company (later known as Royal Dutch Petroleum Company) established an oil company with 'Shell' Transport and Trading Company in 1898. Royal Dutch had successfully penetrated the oil pool in East Sumatra earlier on before 1889. ${ }^{45}$ This was comparable to the British in Borneo, who succeeded in huge oil exploration in Sarawak sometime later.

\section{Charles Brooke invited Shell}

James Brooke's successor Charles Brooke became attracted to the Baram district when he was informed by A. H. Everett that the area was potentially strategic in helping the British East India Company gather dominance in the oil industry. ${ }^{46}$ During the early 1900 s, it was evident 
that the oil industry had supported Charles Brooke's mission when the increase of oil demand in the European market contributed to Sarawak's earnings.

Following Everett's prediction and expectation, Charles Brooke forced himself to participate in the industry by directly taking the first step in subjugating Baram district in 1882 . Prior to his intention about the industry, Charles Brooke had continued to press the British to purchase the concession in Baram, since the British had seemed reluctant to get directly involved. ${ }^{47}$

In August 1881, the British assigned the North Borneo Chartered Company to administer Sabah as a British Protectorate. ${ }^{48}$ The North Borneo Chartered Company was also involved in sponsoring an equally expansionist trading company with the British East India Company in North Borneo. ${ }^{49}$ Later, in 1882, the British permitted the purchase of Baram district from Brunei to Sarawak. However, local people in Baram rebelled, and it forced Charles Brooke to interfere in the dispute. Sultan Brunei agreed to leave the district of Baram to the British in lieu of an annual gratuity to the Sultan. ${ }^{50}$

Sarawak's oil industry owed much to Dr. Charles Hose, a British zoologist who also succeeded De Crespigny as the Resident of Baram District in 1888. Hose was certain that with proper management and skill, the oil could be worked commercially. ${ }^{51}$ His advice to Rajah Brooke had compelled the granting of a concession agreement between the Government of Sarawak and Anglo-Saxon Petroleum Company (known as Shell) in 1909. Hose persuaded Anglo-Saxon Petroleum to employ capital in oil exploration in Sarawak that was represented by Asiatic Petroleum.

The grant to exploit the oils in Miri in 1909 proved to be successful when the Chairman of Asiatic Petroleum, Marcus Samuel, reported finding oil at Miri and employed a capital of GBP500,000. ${ }^{52}$ Anglo-Saxon Petroleum or Asiatic Petroleum succeeded in having the sole right to explore for oil throughout the State. In October 1910, oil was struck at a depth of 447 feet and the well-produced 4 tons per day. This was the first time in Malaysian petroleum history that Miri was recorded as a significant oil producer in the British Empire. ${ }^{53}$ When the drilling went much deeper at 805 feet, it could produce 90 barrels per day. In 1920, the oil yield increased production of 2,200 barrels at 1,700 feet. ${ }^{54}$ The production continuously increased to 13,000 barrels per day in 1924 from just 90 barrels at the beginning of exploration. ${ }^{55}$

During this time, Sarawak was placed on the list of the British Empire's oil-producing countries. Prior to that, Sarawak used to obtain oil at their refineries in Sumatera and made the first shipment of crude oil to Egypt. Worldwide petroleum production was increasing every 10 years until the oil price increased in 1973. The year 1913 witnessed the earliest "boom" production in the world, producing 51 million tons, and Miri played a part in it. ${ }^{56}$

\section{PROTECTIONISM OF OIL PRODUCER COLONIES}

In the early $20^{\text {th }}$ century, Britain's policy of protectionism began to be imposed on its oil producer colonies. ${ }^{57}$ This new policy was due to the British Empire facing a threat from the unification of Germany. The British also witnessed the defeat of France in the Franco-Prussian War that completed the unification of Germany. The concerns of the British over the unification 
of Germany proved correct when it created the European wars that led to the First World War in 1918.

Prior to the First World War, the British strategized to subjugate and consolidate their Eastern colonies including Sarawak, rich with oil, to prevent them from falling into Germany's hands. As a result, the British government had to tighten national security, improve military equipment, and foster its economic system. Oil was the vital resource to pay for maintaining British supremacy.

The policy of protectionism continued into the mid-20 $0^{\text {th }}$ century when the British Empire and the Alliance met the threat from Nazi German and European Fascists. Most importantly, the threat in the Far East and Southeast Asia came from Japanese military occupation in Manchuria and China and expanded to Singapore when the Second World War broke out in 1941. With the outbreak of the Second World War, the British sought oil alliance with Standard Oil to protect their petroleum property in the Near East and the Far East as well as in Southeast Asia. Following the consolidation of oil partnership in their colonies, the British policy of protectionism widened with Standard Oil's strength in its oil domain.

\section{The Fuel Forces for British Navy and the First World War}

The First World War demonstrated a stronger policy of protectionism on the part of the British. Winston Churchill consolidated oil-producing colonies through his Admiral, John Fisher. The war-time policy was to prevent oil supply from going to the Axis countries. It was a strong measure to tighten British security by elevating the British Navy's ammunitions so that it would be stronger than the Axis armies.

The British government strengthened its naval forces with formidable speed from the ousting of coal by petroleum and improved ammunitions through the by-products of petroleum consumption. ${ }^{58}$ Opportunities to consume more oil came when the British used their colonies, including Sarawak, to serve energy sources from oil to further reinforce naval forces.

Policies promoting oil business expansion in the Far East became easier under the patronage of the British Empire. Politically, the principal purpose was to serve the British Navy by securing oil supply. The policy was similar in Sarawak, where Shell was asked by Rajah Brooke to store a certain amount of oil for the use of the British Navy; he also insisted that a clause to this effect be inserted in the concession. ${ }^{59}$

British policy made it compulsory that oil must be accumulated by oil companies in the colonies to be allotted for the purpose of strengthening British military equipment and operations. If the British oil companies did not supply enough for the military's fuel consumption, then collaboration with other nations could help produce more oil through the consolidation of colonies with allies.

This effort was initiated by Marcus Samuel, whose enthusiasm for developing markets for fuel oil was equal to that of the British Admiral, Sir John Fisher; this later made him eager to come to an arrangement with the Navy. Samuel had to develop his European plans; he approached the British Admiralty to get them to convert their fleets from coal to oil and to use his Texan oil from Russia. Indeed, at various times during the period from 1902 to 1911, Samuel had suggested putting a British government director on the Shell board to make it easier to gain Navy contracts. ${ }^{60}$ 


\section{British Royal Navy’s Conversion to Oil}

The Royal Navy first experimented with fuel oil in 1899. In a public address in September 1882, Admiral Fisher tried to persuade anyone in the British establishment who would listen that Britain must convert its naval fleet from bulky coal-fired propulsion to the new oil fuel. ${ }^{61}$ Fisher and a few other far-sighted individuals began to argue for adoption of the new fuel. He insisted that oil-power would allow Britain to maintain a decisive strategic advantage in future control of the seas.

In 1885, the German engineer Gottleib Daimler developed the first workable petroleum engine to drive a road vehicle. The economic potentials of the petroleum era were beginning to be more broadly realised by some beyond Admiral Fisher and his circle. By 1904, Fisher had been named Britain's First Sea Lord, the supreme naval commander, and immediately set to implement his plan to convert the British Navy from coal to oil. One month into his post, in November 1904, a committee was established on his initiative to "consider and make recommendations as to how the British Navy shall secure its oil supplies". At that time, it was believed that the British Isles, rich in coal, did not hold a drop of oil. ${ }^{62}$

The thought of abandoning the security of domestic British coal fuel in favour of reliance on foreign oil was a strategy embedded in risk. The Fisher Committee had been dissolved in 1906 without resolution of the oil issue on the election of a Liberal government that pledged to work for arms control. By 1912, as the Germans began a major Dreadnoughtclass naval construction programme, Prime Minister Asquith convinced Admiral Fisher to come out of retirement to head the new Royal Commission on Oil and the Oil Engine in July 1912.

In 1910, Fisher wrote to Winston Churchill, pressing his point about the urgent need to convert to oil. He wrote, "Your old women will have a nice time of it, when the new American battleships are at sea burning oil alone and a German Motor battleship is cocking a snook at our Tortoise". 63

Two months later, on Fisher's recommendation, the first British battleship using only oil fuel, the Queen Elizabeth, was launched. Fisher pushed the risky oil programme through with one argument: "In war speed is everything". When Churchill was supportive of Fisher's idea, the world was facing an oil shortage. A Royal Commission into Fuel and Engines was appointed in June 1912, with Fisher at its head to point it in the right direction. ${ }^{64}$

Churchill had by then replaced Fisher as First Lord of the Admiralty and was a strong advocate of Fisher's oil conversion. Churchill stated in regard to the Commission finding, "We must become the owners or at any rate the controllers at the source of at least a proportion of the oil which we require". ${ }^{65}$ From that point, oil conversion of the British fleet dictated national security priority to secure large oil reserves outside Britain. In 1913, less than $2 \%$ of world oil production was within the British Empire. ${ }^{66}$

\section{Oil Factor for War}

By the first decade of the $20^{\text {th }}$ Century, securing long-term foreign petroleum security had become an essential factor for the British grand strategy and its geopolitics. By 1909, a British company, Anglo-Persian Oil Company, held rights to oil exploration in a 60-year concession 
from the Persian Shah at Maidan-i-Naphtun near the border with Mesopotamia. The decision to secure its oil led England into a fatal quagmire of war, which in the end finished the British Empire as the world hegemon by Versailles in 1918, though it would take a Second World War and several decades before that reality was clear to all.

The hunger for oil by the British became a Churchillian endeavour to promote the interests of the British Navy and the British Empire. He relied on Fisher to get the oil, on how it could be stored cheaply, as well as how it could regularly be purchased and cheaply in peace, and with absolute certainty in war. ${ }^{67}$

War did indeed break out later, and the British Prime Minister at that time, Winston Churchill, was proven right. Oil was the vital ingredient. By 1918, the tank had demonstrated its worth, as had mechanised transport for the infantry. The Allied armies had over 150,000 trucks in use, 60,000 of them British. The aircraft had come into its own, and the Royal Navy had converted almost its entire fleet to fuel oil. ${ }^{68}$ The British had gained victory over Germany.

Shell and Standard Oil in the Second World War

The outbreak of the Second World War in the Far East had been forcing Shell to cut off communication with more of its properties, and its markets were in disarray. Worse still, Shell's leader, the powerful Henri Deterding, turned pro-Nazi and he compensated Shell's properties in Russia to prevent Communist domination. Consequently, there was a tendency for the members of the Shell group to become less well-coordinated and to go their separate ways. ${ }^{69}$

After Deterding's death in 1939, the Nazis tried to control Shell. This created fear among the British, who were worried that British oil control would be undermined. Britain immediately shifted Deterding's share in Shell to other directors. Significantly, because of the fear of Nazi domination over their oil establishment, British oil companies, including Shell, merged their downstream activities into the Petroleum Board, in effect creating a national monopoly under a new single brand name 'Pool'. ${ }^{70}$

The British were facing a global oil issue, expecting Germany to obtain an abundant supply of Russian oil, while the British supply from the Far East would be curtailed if the Japanese invaded Southeast Asia. This would also affect American oil business in British and French colonies. Esso and Chevron (then, Standard Oil of California), which belonged to the US, followed other British oil companies such as British Petroleum (then, the Anglo-Iranian Oil Company) in supplying oil to the national military as propagated by Churchill to help the Alliance military mobilise faster with naval forces. ${ }^{71}$

Churchill was also worried that oil companies from the Alliance countries would supply oil to Fascist forces if there were no measure to consolidate and dictate British and American oil companies during the war; the axis would strengthen their proxies with effectively mobilised forces.

This happened when a Chief Executive Officer of Texaco Oil Company, Torkild Rieber, made connections with German Nazism and supplied oil to Fascist forces during the Spanish Civil War. This worsened when it happened to Shell when Deterding began to admire the German Fascists and made negotiations with the Fascist government to purchase oil with credit in Russia. ${ }^{72}$ 
In Borneo, the Fascist army was led by Japanese forces. They succeeded in squeezing the British out and capturing oil infrastructure. The Japanese made strenuous efforts to repair Sarawak oil installations and bring oil fields back into production. Japanese oil production reached its peak from the Miri and Seria oilfields in 1944, though not as much as in pre-war production. ${ }^{73}$ Both oil fields produced a total of 11,498,000 barrels during the whole period of occupation, with an estimated 10,645 barrels per day. In 1942, the fields produced around 410,800 barrels, rising to 792,300 in 1943 ; a year later plunging to only $364,000 .{ }^{74}$ On 15 August 1945, the Japanese surrendered Malaya over to the British. In Borneo, Australian forces captured Japanese forces and returned the oil properties to the Allies.

\section{Post-War Oil Industry in Sarawak}

After the Second World War, the British rebuilt oil infrastructure in their colonies affected by the destruction of war. The British prolonged colonisation in Malaya, as there was the opportunity to capitalise on petroleum resources with the increase in world demand. Before the Fascists or Japanese occupied the British colonies prior to the outbreak of war in Southeast Asia, much of the oil infrastructure had been destroyed by the British themselves. The period following World War II witnessed the British rebuilding the Miri oilfield after experiencing oil activities in the 1920s, which had contributed more than considerable income to the colony.

The period of post-war oil activity is known the Rehabilitation period, an attempt to return to the days of prosperous oil production before World War II. Post-war oil production in Sarawak was reconstructed after the Australian army and Shell's technicians completed the huge task of putting out 377 oil-well fires. ${ }^{75}$

Shell was rebuilt and recovered, aided for once by a British Treasury agreement in 1946, freeing it from exchange controls and permitting oil payments in sterling rather than scarce dollars, a slight advantage over American companies. ${ }^{76}$ Shell employed recapitalisation for exploration and geological surveys in Borneo with USD168 million. From this period until the 1950s, not much oil activity happened, and production in Miri never reached the pre-war levels. Only once in 1956 did production pass the half a million-barrel mark. ${ }^{77}$

In the post-war case, oil production was not as expected. The war caused a catastrophe in the British Empire and entailed a lot of expenditure in colonies' administration. Decreased income from oil-producing colonies also led to the decolonisation policy, which brought independence to Malaya and Borneo in later years.

\section{The Oil Industry After Independence}

After Malaysia's Independence in 1957, the new government continued the concession agreement policy with FOC as previously implemented by the British. Again, Shell and Esso (previously known as Standard Oil) dominated the oil market share in Malaya and Borneo as they had been in the market during British colonisation. In deference to the concession system, oil activities needed to follow the terms of the contract provided by the Malaysian government. This adheres to the concession agreement by which FOCs are known as licensees rather than contractors. 
In a concession agreement, production ownership was possessed by the FOC rather than the Malaysian government, which only acted as the host country. The role of the host country is only limited to collecting royalty and tax out of FOC revenue. The concession area is limited, which the FOC is subjected to follow, usually by the demarcation of the national territory (including the offshore area) into blocks. Furthermore, the award of concession is only for a limited number of blocks. ${ }^{78}$

By 1964, only Shell Sarawak and Shell Sabah held oil concessions in Malaysia. However, the number of bidders and concessionaires has increased since the passing of the Continental Shelf Act of 1966. With this development, the crude oil industry in Malaysia was no longer dependent on the monopoly of one company, and this improved the negotiating position of the government vis-à-vis the oil companies. ${ }^{79}$

\section{Impact of FOC to the Establishment of PETRONAS}

Petroliam Nasional Berhad (PETRONAS) was born in the context of the crisis created when the Middle Eastern countries were implementing a six-month oil embargo on FOC in 1973, which resulted in an increase in oil prices. ${ }^{80}$ The Malaysian government took the initiative to control oil prices, and this became a major incentive for the government to seek means of increasing equity of profits in the oil industry by establishing the National Oil Corporation (NOC).

In 1974, the Malaysian government decided to place the mining of oil resources under the exclusive ownership and management of the NOC named Petroliam Nasional Berhad (PETRONAS). The affirmative programme was also implemented to enhance the Malays' social and economic conditions after the introduction of the New Economic Policy (NEP) promulgated in 1970.

The primary aim of the government in establishing PETRONAS was to protect one of the natural resources of the country, namely crude oil, from foreign domination and exploitation. This purpose is a replication of the British policy of protectionism during the period of colonisation. The establishment of PETRONAS for national agenda is a consequence of the policy of petroleum nationalisation. It was a continuation of economic reform under the NEP. The policy of protectionism in oil business arose spontaneously when Malay elites expanded the NEP agenda to acquire more ownership in mining equity for the Malays, which later led to the founding of PETRONAS. In other words, the establishment of PETRONAS has the implicit purpose of achieving the objectives of the NEP.

The NEP is a replication of idea and history of oil protectionism and monopoly during British colonialism through investments and exploration of FOCs in Malaya from the time of British rule until the establishment of PETRONAS. These FOCs include major international oil companies such as Royal Dutch Shell (operating from the 1910s to 1970s) and ExxonMobil Corporation (operating from 1960s to 1970s). Later, PETRONAS adopted protectionism and monopoly strategies to increase equity ownership of Malays in the oil and mining industry. 


\section{CONCLUSION}

When the American Standard Oil Company dominated oil distribution and trading in the Far East and Southeast Asia, it led the British and the Dutch to control oil exploration and production in their colonies in Southeast Asia to prevent Standard Oil's access to cheaper oil supply. This marked the beginning of a policy of oil protectionism by the British in Southeast Asia.

When the British-Dutch oil company was formed in 1903, it became the Royal Dutch Shell Petroleum Company, a coalition to supersede Standard Oil's supremacy in Southeast Asia. In the early 20th century, Royal Dutch Shell succeeded in dominating the oil supply in Southeast Asia after implementing the partnership strategy with local people and the British government. The Royal Dutch imposed the Straight Line policy where cheaper oil could be produced in Borneo by establishing total operation of oil production close to oil deposits and conducting exploration activities.

When oil was found in Sarawak, the partnership strategy proved to be a success. This discovery was a potential deposit for massive production. It was proven that in the early 20th century, Sarawak was placed on the British Empire's list of oil-producing countries. As a result, the British oil capitalists were able to maintain the production of cheaper oil in Southeast Asia. This overshadowed Standard Oil's dominance over oil distribution in the region. The success of Shell in obtaining oil market share in Southeast Asia was due to the implementation of the policy of protectionism, where the colonies in Malaya, Borneo, and Sumatera were in the hands of the British and Dutch Empires.

In Borneo particularly, the Brooke government made an agreement with the British Protectorate to supply most of the oil discovered to the British Navy. To secure this relationship, only the Royal Dutch Shell had full control over petroleum exploration and oil supply in Southeast Asia. This practice of protectionism negated the advocacy of the British free-market policy in its colonies. In addition, British protectionism resulted in their realisation of bringing back a policy of 'pseudo-mercantilism'.

The First World War and the Second World War demonstrated a stronger policy of protectionism on the part of the British. Winston Churchill consolidated oil-producing colonies through his Admiral, John Fisher. The war-time policy was to prevent oil supply from going to the Axis countries. It was a strong measure to tighten British security by elevating the British Navy's ammunitions so that it would be stronger than the Axis armies.

The independence of Malay States and Sarawak followed when the British declared the decolonisation policy. The newly independent government maintained the oil concession agreement with FOC, as was practised by the British during colonisation. Shell and Esso (previously known as Standard Oil) were allowed by the new government to continue their business operations in Southeast Asia.

The FOCs' early engagement with the new government after independence was for a new concession agreement to explore and search for new oil fields. Later, the new government made concession agreements with FOCs to explore more offshore oil deposits in Borneo as well as in the Malay Peninsula.

When the new government realised that oil was the principal source of income for the nation, the formation and establishment of the National Oil Company (NOC) became an 
important national agenda. PETRONAS became the key player in carrying out this agenda, and thus became the sole representative of the oil industry in Malaysia.

This shows that by introducing the idea of NOC, the legacy of oil protectionism during colonisation resurfaced as a common practice in the oil industry.

\section{ENDNOTES}

${ }^{1}$ Eric Roll, Sejarah Pemikiran Ekonomi, trans. Adzman Shamsudin, Dewan Bahasa dan Pustaka 1995 (Kuala Lumpur: 1995), p. 71.

${ }^{2}$ According to Eli F. Heckscher, the essence of mercantilism natural to its economic system is nationalism. The Dutch and the British competed to dominate international trade in the Baltic Sea. Most economic scholars in the 18th century tried to compare the economic superiority and social class between Holland, Hamburg, England, and France. According to Adam Smith, Holland and Hamburg were composed chiefly of merchants, artificers, and manufacturers, whereas England and France consisted of proprietors and cultivators. Holland, Smith further thought, was a richer country than England. See Heckscher, Eli F, Mercantilism, Volume II, translated by Mendel Shapiro, $2^{\text {nd }}$ edition by E.F. Soderlund (London: George Allen \& Unwin Ltd, 1955) p. 1. See also Charles P. Kindlerberger, Historical Economics, Arts or Science? Harvester Wheatsheaf (London: 1990), pp. 109-110.

${ }^{3}$ William O. Henderson, Friedrich List: Economist and Visionary, London, Franck Cass, 1983; Keith Tribe, "Die Vernunft des List: National Economy and the Critique of Cosmopolitan Economy," in Strategies of Economic Order: German Economic Discourse, 1750-1950, Cambridge, Cambridge University Press, 1995, pp. 32-47.

4 Christopher Tugendhat and Adrian Hamilton, Oil: The Biggest Business, Eyre \& Spottiswoode Ltd., (London: 1968), p. 4.

5 John H. Drabble, An Economic History of Malaysia 1800-1990: The Transition to Modern Economic Growth, Macmillan Press Ltd., (London: 2000), p. 38.

${ }^{6}$ Oil Standard Company founded by John D. Rockefeller and his partners began to manufacture kerosene in the largest refinery in Cleveland. Exxon, Mobil and Socal are its offspring. The 1911 antitrust case resulted in the dissolution of Standard Oil into thirty-four companies, nine of which had foreign operations.

${ }^{7}$ Muhammad Anuar Adnan, "The Petroleum Industry in Malaysia", British Doctoral Thesis, The British Library, University of London, (London: 1978), p. 16.

${ }^{8}$ Paul Horsnell, Oil in Asia, Market, Trading, Refining and Deregulation, Oxford Institute for Energy Studies (Oxford University Press:1997), p. 134.

${ }^{9}$ Muhammad Anuar Adnan, "The Petroleum Industry in Malaysia", p. 23.

${ }^{10}$ Ibid.

${ }^{11}$ www.exxonmobil.com.my/History of Esso in Malaysia.

12 Ibid.

${ }^{13}$ Ibid.

${ }^{14}$ Muhammad Anuar Adnan, "The Petroleum Industry in Malaysia”, p. 14.

${ }^{15}$ Ibid, p. 15.

${ }^{16}$ Grondpeilwezen in, "A Hundred Years of Unity in Diversity", Royal Dutch Petroleum Company 1890-1990, Shell Ltd., (London: 2001), p.32

${ }^{17}$ Ibid., p. 33

${ }^{18}$ Muhammad Anuar Adnan, "The Petroleum Industry in Malaysia” p. 22.

${ }^{19}$ Louis Turner, Oil Companies in the International System, The Royal Institute of International Affairs, George Allen \& Unwin, (London: 1978 ), p. 25. 
${ }^{20}$ Ibid.

${ }^{21}$ Deterding called it from the pre-1907 era. The policy was that it produced its own oil and its production was much closer to its market. Supply crude by purchase or production from low cost sources to market.

${ }^{22}$ Muhammad Anuar Adnan, "The Petroleum Industry in Malaysia", pp. 41-42.

${ }^{23}$ Grondpeilwezen in, "A Hundred Years of Unity in Diversity", p. 32.

${ }^{24}$ Muhammad Anuar Adnan, "The Petroleum Industry in Malaysia", p. 22.

${ }^{25}$ Ibid., pp. 40-41.

${ }^{26}$ Daniel Yergin, The Prize: The Epic Request for Oil, Money and Power, Simon \& Schuster (New York: 1998), p. 33.

${ }^{27}$ Grondpeilwezen in, "A Hundred Years of Unity in Diversity”, p. 33.

${ }^{28}$ Ibid.

${ }^{29}$ Ibid.

${ }^{30}$ Muhammad Anuar Adnan, "The Petroleum Industry in Malaysia" p. 36.

${ }^{31}$ Oystein Noreng, Crude Power, Politics and the Oil Market (I.B Tauris Publishers: London, 2002), p. 56.

32 Ibid.

${ }^{33}$ Louis Turner, Oil Companies in the International System, p. 25.

34 James Bamberg, The History of the British Petroleum Company: Volume 2, Cambridge University Press, (Cambridge: 1994), pp. 277-278.

${ }^{35}$ Muhammad Anuar Adnan, "The Petroleum Industry in Malaysia", p. 36.

${ }^{36}$ Michael T. Klare, Blood and Oil, Penguin Books, (London: 2004), p. 117.

${ }^{37}$ John H. Drabble, An Economic History of Malaysia, p. 52.

${ }^{38}$ Barbara Watson Andaya, A History of Malaysia, p. 128.

${ }^{39}$ John H. Drabble, An Economic History of Malaysia, p. 101.

${ }^{40}$ Barbara Watson Andaya, A History of Malaysia, p. 131.

${ }^{41}$ Ibid.

42 John H. Drabble, An Economic History of Malaysia, p. 102.

${ }^{43}$ Muhammad Anuar Adnan, "The Petroleum Industry in Malaysia", p. 45.

${ }^{44}$ Ibid., p. 35.

${ }^{45}$ Grondpeilwezen in "A Hundred Years of Unity in Diversity", p. 30.

${ }^{46}$ Muhammad Anuar Adnan, "The Petroleum Industry in Malaysia" p. 40.

${ }^{47}$ Barbara Watson Andaya \& Leonard Y. Andaya, A History of Malaysia 2nd ed., Palgrave Publisher Ltd., (Hampshire: 2001), p. 190.

${ }^{48}$ Protectorate presented as indirect rule of the British over the colony. It was a formal label that the colony was under the protection of British Government. In Malaysian historical context, this system resulted from the Pangkor Treaty of 1874, which recognized Abdullah as Sultan of Perak in return for his agreement to accept a British Resident. The Resident's advice must be asked and acted upon all questions other than touching Malay or local religion and custom. This system was also imposed on four other British protectorate states, Selangor, Johor, Negeri Sembilan and Pahang.

${ }^{49}$ Barbara Watson Andaya, A History of Malaysia, p. 187.

50 Ibid.

${ }^{51}$ Muhammad Anuar Adnan, "The Petroleum Industry in Malaysia”, p. 40.

52 Ibid., p. 42.

${ }^{53}$ Ibid., p. 46.

54 Ibid.

55 John H. Drabble, An Economic History of Malaysia, pp. 52-53.

${ }^{56}$ Ibid., p. 72. 
${ }^{57}$ Gerard M. Koot, "Historical Economics and the Revival of Mercantilism Thought in Britain, 1870-1920”, Mercantilist Economy , ed. Las Magnusson, Kluwer Academic Publishers, (Boston: 1993), p. 187. "A century after Adam Smith's critique of mercantilism, and a mere quarter century after the triumph of free trade in Britain, some economists and economic historians began to question the wisdom of free trade policies for a Britain that now faced the competition of a united Germany and a dynamic United States, both of which turn to protection. For many, the repeal of the Corn Law in 1846 had seemed to usher in an age of unprecedented freedom of movement of capital, goods and labor. It was fervently hoped that free trade would be adopted by other nations."

${ }^{58}$ Anton Mohr, The Oil War, Harcourt Brace \& Co., (New York: 1926), p. 30.

${ }^{59}$ Muhammad Anuar Adnan, "The Petroleum Industry in Malaysia”, p. 48.

${ }^{60}$ Ibid., p. 49.

${ }^{61}$ Eric J. Dahl, "Naval Innovation: From Coal to Oil“" Joint Force Quarterly, Winter (London: 2000), p. 130.

62 Ibid., p. 131.

${ }^{63}$ Anton Mohr, The Oil War, p. 39.

${ }^{64}$ Peter Slulgett, Britain in Iraq: 1914-1932, Ithaca Press (London: 1976), p. 104.

65 Ibid., p. 104.

${ }^{66}$ The details on oil versus coal powered ships are found in Anton Mohr, The Oil War, (New York: Harcourt, Brace \& Co., 1926), pp. 113-115. Anton Zischka, Oelkrieg: Wandlung der Weltmacht Oel, Leipzig, Wilhelm Goldmann Verlag: 1939), p. 293 for additional comparative data of oil over coal.

${ }^{67}$ Ibid.

${ }^{68}$ Muhammad Anuar Adnan, “The Petroleum Industry in Malaysia”, p. 42.

${ }^{69}$ William N. Greene, Strategies of the Major Oil Companies, UMI Research Press, (London: 1985), p. 223.

70 Ibid.

${ }^{71}$ James Bamberg, The History of the British Petroleum Company, pp. 277-279.

72 William N. Greene, Strategies of the Major Oil Companies, p. 225.

${ }^{73}$ Muhammad Anuar Adnan, "The Petroleum Industry in Malaysia”, p. 57.

74 Ibid.

${ }^{75}$ Ibid., p. 60.

${ }^{76}$ William N. Greene, Strategies of the Major Oil Companies, p. 226.

${ }^{77}$ Muhammad Anuar Adnan, "The Petroleum Industry in Malaysia”, pp. 61-63.

${ }^{78}$ Blinn, Keith W., International Petroleum Exploration \& Exploitation Agreements: Legal, Economic, and Policy Aspects, Barrows, (New York: 1990), p. 62.

${ }^{79}$ Muhammad Anuar Adnan, "The Petroleum Industry in Malaysia", p. 104.

${ }^{80}$ Beginning of 1972 , the price of oil was US\$1.50/BBL (barrel) and then rose to US\$2.28. Due to the war in the Middle East, the OPEC raise the price to US\$12.00/BBL in 1973. See the article wrote by R. Von Der Maiden \& Al Troner, "PETRONAS: A National Oil Company With An International Vision", Research, The James A . Baker III Institute For Public Policy, Rice University, 2007, p. 3.

\section{REFERENCES}

British Government. ASIATIC Petroleum. Petroleum Regulation. File 4970/1894, Jabatan Arkib Negara, Malaysia, 1913.

"Condour About Tin Restriction, Should the Agreement Been Renewed? Malayan Miners Must Make Up Their Minds", The Straits Times, 17 April 1935. 
"Floating in Oil", The Economist, 9 October 1971.

"Malaysia's PETRONAS: A Legislative Overskill”, Far Eastern Economic Review, 16 May 1975.

"Oil Companies in Malaysia: An Uncertain Feeling”, The Financial Times, 3 June 1975.

"Oil Investment Return by 28 Firms Fell Here and Abroad, Bank Says", Wall Street Journal, 6 August 1971.

“OPEC Resolutions Seek Participation”, Financial Times, 14 August 1971.

PETRONAS, Sedekat Pembangunan PETRONAS, PETRONAS, Kuala Lumpur: 1985.

PETRONAS, Petronas dan Industri Petroleum Malaysia, Jabatan Hal Ehwal Awam, PETRONAS, Kuala Lumpur, 1984.

"The Next Oil War Has Begun", The Economist, 31 July 1971

Abraham, Collin E. R., Divide and Rule: The Roots of Race Relations in Malaysia, INSAN, Petaling Jaya: 1997.

Adnan, Muhammad Anuar, "The Petroleum Industry in Malaysia", British Doctoral Thesis, The British Library, University of London: 1978.

Adnan, Muhammad Anuar, "Extractive Industries", The Political Economy of Malaysia, ed. E.K Fisk and H. Osman Rani, Oxford University Press, Kuala Lumpur: 1982.

Andaya, Barbara Watson and Andaya, Leonard Y., A History of Malaysia, 2nd edition, Palgrave Publisher Ltd., Hampshire: 2001.

Bamberg, J. 1994. The History of the British Petroleum Company: Vol. 2, Cambridge University Press, Cambridge.

Bentham, R. W., and W. G. Smith. 1986. State Petroleum Corporations: Corporate Forms, Power and Control, the Centre for Petroleum \& Mineral Law Studies, University of Dundee, Scotland.

"Better Terms for Exploration", Petroleum Economist: The International Energy Journal, Vol.IV, Num. 6, October 1984.

Blinder, A. S. 1980. Economic Policy and the Great Stagflation, Academic Press, New York.

Blinn, K. W. 1980. International Petroleum Exploration and Exploitation Agreements: Legal, Economic, and Policy Aspects, Barrows, New York.

Dahl, E. J. 2000. Naval Innovation: From Coal to Oil“" Joint Force Quarterly, Winter, London.

Drabble, J. H. 2000. An Economic History of Malaysia 1800-1990: The Transition to Modern Economic Growth, Macmillan Press Ltd., London.

Gerretson F.C. 1985. History of the Royal Dutch: Volume 1, E. J. Brill, Leiden.

Greene, W. N. 1985. Strategies of the Major Oil Companies, UMI Research Press, London.

Grondpeilwezen, "A Hundred Years of Unity in Diversity", Royal Dutch Petroleum Company 1890-1990, Shell Ltd., London: 2001.

Hartley, A.G. 1976. Offshore Petroleum Exploration in East Asia: An Overview”, OSEA Conference, Singapore.

Hashim, Ismail, The Young Turks of PETRONAS, Art Printing Works, Kuala Lumpur: 2004.

Heckscher, E. F. 1955. Mercantilism, Volume II, trans. Mendel Shapiro, $2^{\text {nd }}$ edition, ed. E.F. Soderlund, George Allen \& Unwin Ltd, London.

Henderson, W. O. 1983. Friedrich List: Economist and Visionary, London, Franck Cass.

Hirschman, C. 1986. The Making of Race in Colonial Malaya: Political Economy and Racial Ideology", Sociological Forum, Vol. 1, Issue 2, Spring.

Jennings, L. J. 1996. English Trade and Foreign Competition", The Quarterly Review, Free Trade and Protectionism: Volume II, From Free Trade to Fair Trade 1850-1902, ed. Peter Cain, Routledge/Thoemmes Press, London.

Kindlerberger, C. P. 1990. Historical Economics, Arts or Science?, Harvester Wheatsheaf, London.

Klare, M. T. 2004. Blood and Oil, Penguin Books, London. 
Koot, G. M. 1993. Historical Economics and the Revival of Mercantilism Thought in Britain 1870-1920", Mercantilist Economy, ed. Las Magnusson, Kluwer Academic Publishers, Boston: 1993.

Krapels, E. N. 1980. Oil Crisis Management, Strategic Stockpiling for International Security, the John Hopkins University Press, London.

Kunio, Y. 1988. The Rise of Ersatz Capitalism in Southeast Asia, Oxford University Press, Singapore.

Mohr, A. 1926. The Oil War, Harcourt Brace \& Co., New York.

Moorthy V. K., PETRONAS, Its Corporate and Legal Status, Malayan Law Journal, Kuala Lumpur: 1983.

Noreng, O. 2002. Crude Power, Politics and the Oil Market, I.B Tauris Publishers: London.

O'Rourke, K. H., and J. G. Williamson. 2000. Globalization and History: The Evolution of Nineteenth-Century Atlantic Economy, The MIT Press, London.

Tribe, K. 1995. "Die Vernunft des List: National Economy and the Critique of Cosmopolitan Economy," Strategies of Economic Order: German Economic Discourse, 1750-1950, Cambridge, Cambridge University Press.

Tugendhat, C., and H. Adrian. 1968. Oil: The Biggest Business, Eyre \& Spottiswoode Ltd., London.

Turner, L. 1978. Oil Companies in the International System, The Royal Institute of International Affairs, George Allen \& Unwin, London.

SAIFUL KHAIRI KAMARUDIN

Human Capital, Pos Malaysia Berhad

Petaling Jaya, Selangor, Malaysia

*Corresponding author: khairi80@hotmail.com 